\title{
DCF Valuation of Nonprofit Universities
}

\author{
Yan $\mathrm{He}^{1}$, Frank Long ${ }^{2}$ \\ ${ }^{1}$ School of Business, Indiana University Southeast, New Albany, USA. \\ ${ }^{2}$ Strategic Decision Research Center, Wuhan University, Wuhan, China. Duke Kunshan University, Kunshan, China \\ Correspondence: Frank Long, Strategic Decision Research Center, Wuhan University, Wuhan, Hubei 430000, China; \\ Yan He, School of Business, Indiana University Southeast, New Albany, Indiana 47150, USA.
}

Received: October 8, 2019

doi:10.11114/afa.v6i1.4553
Accepted: October 28, $2019 \quad$ Available online: November 8, 2019

URL: https://doi.org/10.11114/afa.v6i1.4553

\begin{abstract}
We conduct the Discounted Cash Flow (DCF) valuation of two nonprofit organizations: Syracuse University and Indiana University. We transform nonprofits to for-profits by converting nonprofit social benefit to net earnings and by adopting for-profit cost of equity and tax rate. These adjustments attempt to capture considerable hidden value to equityholders. We find that in the best scenario, the net worth (market value of equity) could be about 2 times the book equity for both universities in June 2017.
\end{abstract}

Keywords: DCF valuation, nonprofit universities, value creation, social benefit

\section{Introduction}

Nonprofit universities in the U.S. distribute most of their earnings as scholarship and financial aid to students, pay zero tax, and incur zero cost for financing with donated equity capital. This poses two challenges to financial analyses of such institutions. First, it is difficult to estimate their net worth (market value of equity) due to their low levels of net earnings and free cash flows as well as zero cost of equity. Second, it is difficult to directly compare nonprofits with for-profits in terms of financial performance and net worth.

Recent literature has explored several corporate finance aspects of nonprofit institutions. Adelino, Lewellen, and Sundaram (2015) examine the investment-cash flow sensitivity for nonprofit hospitals and find it similar to that for shareholder-owned corporations. Jegers (2011a) shows the existence of financing constraints when nonprofits have no substantial fundraising opportunities to increase revenues and their managers are unwilling to exert high fundraising efforts. Jegers (2011b) detects that tighter equity constraints are associated with more debts to total assets for Belgian nonprofits. Jegers and Verschueren (2006) argue that equity is cheaper than debt for nonprofits, and report that almost half of Californian nonprofits use no debts at all. Based on their profitability study of Norwegian banks, Bøhren and Josefsen (2013) report that stockholder-owned banks do not outperform nonprofit ones. Kalodimos (2017) documents that stronger internal governance of nonprofit hospitals results in better performance as measured by the heart attack survival probability. With their investigation of the hospital takeover market, Gertler and Kuan (2009) find that a nonprofit hospital tends to be sold at a lower price to a "like-minded" nonprofit buyer than to a for-profit buyer, by the measure of Tobin's $q$.

We conduct the Discounted Cash Flow (DCF) valuation of nonprofit universities in this paper. The DCF valuation of for-profit companies has been fully illustrated by Pinto, Henry, Robinson, and Stowe (2015), Koller, Goedhart, and Wessels (2015), and Damodaran (2012 and 2018). Given the nonprofit problems of low earnings and zero equity cost, we adjust nonprofit net earnings, free cash flows to equityholders (FCFE), cost of equity, and tax rate to fit into the for-profit model. This way, the nonprofit net worth can be estimated when acquired by for-profits. Since the DCF approach is mainly for analyzing a concentrated investment (rather than a diversified investment), it is neither possible nor necessary to test a large sample of institutions. Thereby, we choose two representative universities (private and public each) to parse their DCF valuation in detail. Syracuse University (SU) at Syracuse, New York is a nonprofit private organization that does not receive any government appropriations. Indiana University (IU) at Bloomington, Indiana, with a few other branches located in the state, is a nonprofit public organization that receives state appropriations. For both, the current time refers to June 2017, and the 10-year historical period ranges from June 2007 to June 2017. The potential investors or acquirers are assumed to be for-profit publicly traded companies in the 
education industry. We collect the financial reports and other information of SU and IU from their public sources and obtain the data of the education industry from the website of Professor Damodaran. (Note 1) Two DCF methods, Economic Profit to Equityholders (EP to Equityholders) and Free Cash Flow to Equityholders (FCFE), are applied in the valuation process. The forecasting of future earnings, cash flows, and discount rate is based on the view of for-profit acquirers. Such analysis does not apply to the situation in which the potential acquirers are governments or nonprofit organizations, since different types of investors hold different perspectives on the value of an acquisition target.

Our study yields several findings. First, by transforming nonprofits to for-profits, it captures a considerable Market Value Added (MVA) to equityholders. In the best scenario, as we find, the net worth could be about 2 times the book equity for both SU and IU in June 2017. Second, with the net worth breaking even at the book equity, we show that about half of the existing social benefit could be converted to net earnings, while the rest could be distributed to students. Third, when changing from a nonprofit to a for-profit status, the universities would lose some public-and-government-supported fund revenues, but this potential loss could be offset by a potential increase in tuition revenues. A nonprofit private university like SU seems more likely to achieve such a task than a nonprofit public university like IU because the former relies much less on the supported fund revenues than the latter.

In all, our study provides two contributions to the valuation literature. First, it demonstrates the DCF valuation of nonprofit universities from the view of for-profit acquirers. Such analysis could not be easily conducted in the past due to the unique financial features of nonprofits. Second, it reveals the relationship between institutional fundamentals and net worth. Such exploration is crucial to the value creation process of nonprofit organizations. It can only be achieved by the DCF approach, while other approaches, such as relative valuation and asset valuation, tend to have a limited association with fundamentals.

The remainder of this paper is organized as follows. Section 2 illustrates the DCF valuation process. Section 3 discusses the summary data of potential acquirers and acquisition targets. Section 4 analyzes the net worth valuation results, with the nonprofit social benefit fully converted to net earnings. Section 5 explores the partial social benefit conversion, with the net worth breaking even at the book equity. Section 6 draws the conclusions.

\section{DCF Valuation Process}

We use two DCF methods to estimate the net worth, by following Pinto, Henry, Robinson, and Stowe (2015), Koller, Goedhart, and Wessels (2015), and Damodaran (2012). Based on the first method, the net worth is calculated as the current book equity plus the present value of expected future EPs to Equityholders. Based on the second method, the net worth is calculated as the present value of expected future FCFEs.

Nonprofit universities provide substantial social benefit, such as granting scholarship and financial aid to students each year. Here, the social benefit denotes the amount of money that could be earned by the university as net earnings, but instead is distributed to the public for free. In theory, nonprofit organizations are tax free and they distribute all their profits to students as social benefit, leading to zero net earnings as well as zero return on equity. In addition, their equity financing comes from donations, incurring zero cost of equity. With zero return on equity and zero cost of equity, the annual EP to equityholders becomes zero, and the MVA to equityholders also becomes zero. Therefore, the net worth is equal to the book value of equity. In practice, nonprofits usually retain some profits, giving rise to positive net earnings. But their net earnings tend to be low, as indicated by the unadjusted net profit margin and return on equity measures. (Note 2)

When a nonprofit university is purchased by a for-profit company, the tax payment becomes required, the social benefit distribution becomes non-required, and the cost of equity becomes larger than zero. In this transformation, the amount of social benefit distribution is converted to net earnings, capturing an MVA to equityholders. The discount rate is defined as the cost of equity of the potential acquirer. The tax calculation is based on the tax rate of the acquirer.

Meanwhile, as it changes itself from a nonprofit to a for-profit organization, a university would lose some public-and-government-supported fund revenues, such as gifts (or contributions), grants and contracts, and state appropriations. We assume that the potential loss in these fund revenues would be offset by the potential increase in tuition revenues. That is, the total revenues would not be affected by this change. 
Table 1. DCF valuation process

Panel A. All methods

\begin{tabular}{|l|l|}
\hline Current time & June 2017 \\
\hline Past 10 years & June 2007 to June 2017 \\
\hline Future growth pattern & One-stage constant growth rate for the university \\
\hline $\begin{array}{l}\text { Future growth rate }(\mathrm{g}) \\
\text { First proxy }\end{array}$ & $\begin{array}{l}\text { The first proxy is the geometric average growth rate of the university's adjusted net earnings in } \\
\text { the past 10 years. }\end{array}$ \\
\hline $\begin{array}{l}\text { Future growth rate }(\mathrm{g}) \\
\text { Second proxy }\end{array}$ & $\begin{array}{l}\text { The second proxy is the geometric average growth rate of the university's revenues in the past } 10 \\
\text { years. }\end{array}$ \\
\hline Future cost of equity $(\mathrm{k})$ & Proxied by the average cost of equity of the education industry in the past 10 years \\
\hline $\mathrm{BE}_{0}$ & Book equity of the university at the current time \\
\hline
\end{tabular}

Panel B. EP to Equityholders method

\begin{tabular}{|l|l|}
\hline Adjusted net earnings & $\begin{array}{l}\text { (Reported net earnings } \\
\text { + Reported scholarship and financial aid } * \% \text { of social benefit converted }) \\
*(1-\text { tax rate) }\end{array}$ \\
\hline Adjusted ROE & $\begin{array}{l}\text { Adjusted return on equity } \\
\text { Calculated as the adjusted net earnings divided by prior book equity. }\end{array}$ \\
\hline Future ROE & Proxied by the average adjusted ROE in the past 10 years. \\
\hline $\mathrm{EP}_{1}$ & $\begin{array}{l}\text { Economic profit to equityholders in future year } 1 \\
\mathrm{EP}_{1}=\mathrm{BE}_{0} *(\text { Future ROE }-\mathrm{k})\end{array}$ \\
\hline $\mathrm{NW}_{0}$ & $\begin{array}{l}\text { Net worth of the university at the current time } \\
\mathrm{NW}_{0}=\mathrm{BE}_{0}+\mathrm{MVA} \text {, where MVA }=\mathrm{EP}_{1} /(\mathrm{k}-\mathrm{g})\end{array}$ \\
\hline
\end{tabular}

Panel C. FCFE method

\begin{tabular}{|l|l|}
\hline FCFE & FCFE $=$ Cash flow from operations - Investment in fixed capital + Net borrowing \\
\hline Adjusted FCFE & Adjusted FCFE $=$ FCFE - Reported net earnings + Adjusted net earnings \\
\hline Adjusted FOE & $\begin{array}{l}\text { Adjusted FCFE on equity } \\
\text { Calculated as the adjusted FCFE divided by prior book equity. }\end{array}$ \\
\hline Future FOE & Proxied by the average adjusted FOE in the past 10 years. \\
\hline FCFE $_{1}$ & $\begin{array}{l}\text { Free cash flows to equityholders in future year } 1 \\
\text { FCFE }_{1}=\mathrm{BE}_{0} * \text { Future FOE }\end{array}$ \\
\hline $\mathrm{NW}_{0}$ & $\begin{array}{l}\text { Net worth of the university at the current time } \\
\mathrm{NW}_{0}=\mathrm{FCFE}_{1} /(\mathrm{k}-\mathrm{g})\end{array}$ \\
\hline
\end{tabular}

Table 1 presents the DCF valuation process. Panel A provides illustrations for all the methods used, Panel B for the EP to Equityholders method, and Panel C for the FCFE method. In Panel A of Table 1, the future growth pattern is set up as one-stage constant growth because both the student enrollment and the total revenues of the two universities have climbed slowly in the past. It seems unnecessary to use a two-stage or three-stage pattern. The future growth rate (g) has two proxies: one is based on the average growth rate of the university's adjusted net earnings in the past 10 years, and the other, the average growth rate of the university's revenues in the past 10 years. The future cost of equity (k) is proxied by the average cost of equity of the education industry in the past 10 years.

In Panel B of Table 1, the future return on equity (ROE) is proxied by the average adjusted ROE in the past 10 years, and the adjusted ROE is estimated as the adjusted net earnings divided by the prior book equity. The adjustment of net earnings is made by adding the converted amount of social benefit to the reported net earnings, and by paying taxes. See Equation (1) below for the definition of the adjusted net earnings.

$$
\begin{gathered}
\text { Adjusted net earnings } \\
=(\text { Reported net earnings } \\
+ \text { Reported scholarship and financial aid *\% of social benefit converted }) \\
*(1-\text { tax rate }) .
\end{gathered}
$$

Specifically, the reported net earnings refer to the increase in net assets, i.e., the bottom line of the income statement. The tax rate means the newly updated marginal tax rate $(21 \%)$ instead of the old rate $(35 \%)$, because the purpose of this calculation is to estimate the future ROE. Finally, the net worth at the current time $\left(\mathrm{NW}_{0}\right)$ is equal to the current book equity $\left(\mathrm{BE}_{0}\right)$ plus the MVA, where the MVA is equal to the projected economic profit to equityholders in future year1 $\left(\mathrm{EP}_{1}\right)$ divided by the difference between cost of equity and growth rate, and the economic profit $\left(\mathrm{EP}_{1}\right)$ is equal to the current book equity multiplied by the difference between the future ROE and the future cost of equity. See Equation (2) below for the net worth calculation.

$$
N W_{0}=B E_{0}+M V A
$$


where MVA $=\mathrm{EP}_{1} /(\mathrm{k}-\mathrm{g})$, and $\mathrm{EP}_{1}=\mathrm{BE}_{0} *($ Future $\mathrm{ROE}-\mathrm{k})$.

In Panel $\mathrm{C}$ of Table 1, the future FCFE on equity (FOE) is proxied by the average adjusted FOE in the past 10 years, and the adjusted FOE is estimated as the adjusted FCFE divided by the prior book equity. The adjustment of free cash flows is made by subtracting the reported net earnings and adding the adjusted net earnings, as presented in Equation (3) below.

$$
\text { Adjusted FCFE }=\text { FCFE }- \text { Reported net earnings }+ \text { Adjusted net earnings, }
$$

where FCFE = Cash flow from operations - Investment in fixed capital + Net borrowing. Lastly, the net worth at the current time $\left(\mathrm{NW}_{0}\right)$ is equal to the projected FCFE in future year1 $\left(\mathrm{FCFE}_{1}\right)$ divided by the difference between cost of equity and growth rate, as displayed in Equation (4) below.

$$
N W_{0}=F C F E_{l} /(k-g) \text {, }
$$

where $\mathrm{FCFE}_{1}=\mathrm{BE}_{0} *$ Future FOE.

\section{Summary Data of Acquirers and Targets}

For-profit publicly traded companies in educational services are regarded as potential acquirers. Table 2 provides summary data of education companies. The average cost of equity is $8.24 \%$, which will be used as the future discount rate in valuing SU and IU. The average percentage of equity out of capital (based on market measures) is as high as $83.73 \%$, implying a financing structure of light debt and heavy equity. We presume that both the cost of equity and the equity to capital ratio will remain constant in the future for the acquirers. Since the tax rate was reduced in January 2018, the new rate $(21 \%)$ will be used to estimate the future ROE and the future FOE for SU and IU. The average growth in net income $(7.51 \%)$, the average growth in revenues $(7.68 \%)$, the average ROE $(12.95 \%)$, and the average price/book ratio (3.59) are much higher than the current growth in net income (-10.92\%), the current growth in revenues $(-3.90 \%)$, the current ROE (3.10\%), and the current price/book ratio (1.95), respectively. The results suggest better performance historically than currently for education companies. The current price/book ratio (1.95) denotes that the net worth of education companies is nearly 2 times the book equity in 2017 .

Table 2. Summary data of education companies

\begin{tabular}{lccc}
\hline & Current year & 10-year average & Future years \\
\hline Cost of equity & $9.42 \%$ & $8.24 \%$ & $8.24 \%$ \\
Equity/Capital & $74.97 \%$ & $83.73 \%$ & $21 \%$ \\
Marginal tax rate & $35 \%$ & $35 \%$ & \\
Historical 5-year average growth in net income & $-10.92 \%$ & $7.51 \%$ & \\
Historical 5-year average growth in revenues & $-3.90 \%$ & $7.68 \%$ & \\
ROE & $3.10 \%$ & $12.95 \%$ \\
Price/Book ratio & 1.95 & 3.59 \\
\hline
\end{tabular}

SU and IU are treated as acquisition targets. Table 3 provides summary data of the targets. Panel A reports the current-year data, and Panel B, the 10-year-average data. In Panel A of Table 3, we note that the two universities are large and comprehensive in general. Specifically, SU is smaller than IU in terms of student enrollment (21,970 vs. 94,698 ), total revenues ( $\$ 1.0$ billion vs. $\$ 3.2$ billion), total assets ( $\$ 2.9$ billion vs. $\$ 5.5$ billion), and book equity ( $\$ 2.0$ billion vs. $\$ 3.9$ billion). The per-student tuition and fees are much higher for SU as a private university than for IU as a public university $(\$ 39,907$ vs. $\$ 15,337)$.

In Panel B of Table 3, first, we find that both the student enrollment and the total revenues of the two universities grow slowly in the past 10 years. The growth rate of student enrollment is $1.42 \%$ for SU and $0.24 \%$ for IU. The growth rate of revenues is $2.43 \%$ for $\mathrm{SU}$ and $2.81 \%$ for IU.

Second, pertaining to the income statement, the student tuition and fee revenues out of total revenues are $84.62 \%$ for SU vs. $41.86 \%$ for IU. The public-and-government-supported fund revenues out of total revenues, including gifts (or contributions), grants and contracts, and state appropriations, are $17.59 \%$ for SU vs. $41.82 \%$ for IU. Additionally, these fund revenues divided by the student tuition and fees are $20.89 \%$ for SU vs. $100.86 \%$ for IU. Therefore, SU relies much less on supported fund revenues than IU. It is noted that $\mathrm{SU}$ as a private university receives zero state appropriations. IU as a public university receives considerable amount of state appropriations, which are 19\% out of total revenues and are equivalent to $45.99 \%$ of student tuition and fees. The costs of scholarship and financial aid out of total revenues are 
$31.21 \%$ for SU vs. $11.99 \%$ for IU; and these costs divided by the student tuition and fees are $36.87 \%$ for SU vs. $28.59 \%$ for IU. That is to say, SU distributes more social benefit to students than IU, since the former charges much higher per-student tuition and fees than the latter. The instructional costs out of total revenues are similar for the two universities (38.47\% vs. $34.34 \%)$.

Third, with regard to the balance sheet, the asset turnover (total revenues divided by total assets) is $34.39 \%$ for SU vs. $61.43 \%$ for IU, suggesting that IU is more efficient in asset usage. The non-current assets contain two major items: the investments which are financial securities such as stocks and bonds, and the fixed assets which are long-term physical assets such as land, land improvements, buildings, and equipment. The investments out of total assets are $45.30 \%$ for SU vs. $26.45 \%$ for IU, and the fixed assets out of total assets are $39.77 \%$ for SU vs. $55.05 \%$ for IU. Thus, SU endures more risk exposure to financial markets. The capital structure measures are similar to those of the education companies, including the long-term debts to total assets ratio (15.75\% for SU vs. $19.04 \%$ for IU), the book equity to total assets ratio (69.05\% for SU vs. $67.14 \%$ for IU), and the book equity to capital ratio ( $81.46 \%$ for SU vs. $76.67 \%$ for IU). Thus, $\mathrm{SU}$ and IU have a capital structure of light debt and heavy equity.

Table 3. Summary data of universities

Panel A. Current-year data (2017)

\begin{tabular}{|c|c|c|}
\hline & Syracuse University & Indiana University \\
\hline Enrollment of students & 21,970 & 94,698 \\
\hline Total revenues (\$million) & 995 & 3,193 \\
\hline Net earnings (\$million) (unadjusted) & 198 & 154 \\
\hline Total assets (\$million) & 2,852 & 5,474 \\
\hline Book equity (\$million) & 2,018 & 3,866 \\
\hline Student tuition and fees per student $(\$)$ & 39,907 & 15,337 \\
\hline \multicolumn{3}{|l|}{ Panel B. 10-year-average data (2007-2017) } \\
\hline Annual enrollment growth & $1.42 \%$ & $0.24 \%$ \\
\hline Annual revenue growth & $2.43 \%$ & $2.81 \%$ \\
\hline Student tuition and fees/Total revenues & $84.62 \%$ & $41.86 \%$ \\
\hline Gifts (or contributions)/Total revenues & $7.65 \%$ & $3.49 \%$ \\
\hline Grants and contracts/Total revenues & $9.94 \%$ & $19.33 \%$ \\
\hline State appropriations/Total revenues & $0.00 \%$ & $19.00 \%$ \\
\hline Scholarship \& financial aid/Total revenues & $31.21 \%$ & $11.99 \%$ \\
\hline Instructional costs/Total revenues & $38.47 \%$ & $34.34 \%$ \\
\hline Net earnings/Total revenues (unadjusted) & $1.88 \%$ & $6.45 \%$ \\
\hline Gifts (or contributions)/Student tuition and fees & $9.16 \%$ & $8.33 \%$ \\
\hline Grants and contracts/Student tuition and fees & $11.73 \%$ & $46.54 \%$ \\
\hline State appropriations/Student tuition and fees & $0.00 \%$ & $45.99 \%$ \\
\hline Scholarship \& financial aid/Student tuition and fees & $36.87 \%$ & $28.59 \%$ \\
\hline Total revenues/Total assets & $34.39 \%$ & $61.43 \%$ \\
\hline Investments/Total assets & $45.30 \%$ & $26.45 \%$ \\
\hline Fixed assets/Total assets & $39.77 \%$ & $55.05 \%$ \\
\hline Long-term debts/Total assets & $15.75 \%$ & $19.04 \%$ \\
\hline Book equity/Total assets & $69.05 \%$ & $67.14 \%$ \\
\hline Book equity/Capital & $81.46 \%$ & $76.67 \%$ \\
\hline ROE (unadjusted) & $1.99 \%$ & $6.42 \%$ \\
\hline FOE (unadjusted) & $-1.50 \%$ & $1.84 \%$ \\
\hline
\end{tabular}

Finally, the net earnings, the net margin (net earnings divided by total revenues), the ROE, and the FOE are unadjusted for social benefit conversion. It is noted that the unadjusted 10 -year average ROE is $1.99 \%$ for SU and $6.42 \%$ for IU, which are much lower than the average ROE of education companies (12.95\%). The unadjusted 10-year average FOE is $-1.50 \%$ for SU and $1.84 \%$ for IU, which are also quite low. Since SU and IU dispense some profits as social benefit each year, they end up with low levels of net earnings and free cash flows to equityholders as well as low ROE and FOE ratios. If the unadjusted average ROE and FOE are used to forecast future net earnings and free cash flows, and if the for-profit cost of equity $(8.24 \%)$ is used as the discount rate, the estimated net worth would be much lower than the book equity, and the MVA to equityholders would be negative. 


\section{Valuation Results: Full Conversion of Social Benefit}

The analysis in this section is based on the best-scenario assumptions summarized as follows. First, the existing social benefit is fully converted to net earnings, i.e., $100 \%$ of scholarship and financial aid are not distributed to students any longer; instead, they are converted to profits. Second, the potential loss of the public-and-government-supported fund revenues is offset by the potential increase in tuition revenues. That is to say, the total revenues remain the same.

Table 4. Valuation results: full conversion of social benefit

Panel A. Inputs and assumptions

\begin{tabular}{|c|c|c|c|c|}
\hline & \multicolumn{2}{|c|}{ Syracuse University } & \multicolumn{2}{|c|}{ Indiana University } \\
\hline & Earnings growth & Revenues growth & Earnings growth & Revenues growth \\
\hline Future growth rate $(\mathrm{g})$ & $3.74 \%$ & $2.43 \%$ & $4.38 \%$ & $2.81 \%$ \\
\hline Future cost of equity (k) & $8.24 \%$ & $8.24 \%$ & $8.24 \%$ & $8.24 \%$ \\
\hline $\mathrm{BE}_{0}(\$$ million $)$ & $2,017.59$ & $2,017.59$ & $3,865.54$ & $3,865.54$ \\
\hline$\%$ of social benefit converted & $100.00 \%$ & $100.00 \%$ & $100.00 \%$ & $100.00 \%$ \\
\hline \multicolumn{5}{|c|}{ Panel B. EP to Equityholders method } \\
\hline Future ROE & $14.12 \%$ & $14.12 \%$ & $14.22 \%$ & $14.22 \%$ \\
\hline $\mathrm{EP}_{1}($ \$million $)$ & 118.78 & 118.78 & 231.25 & 231.25 \\
\hline $\mathrm{NW}_{0}($ \$million $)$ & $4,658.39$ & $4,065.13$ & $9,868.44$ & $8,130.68$ \\
\hline $\mathrm{NW}_{0} / \mathrm{BE}_{0}$ & 2.31 & 2.01 & 2.55 & 2.10 \\
\hline \multicolumn{5}{|l|}{ Panel C. FCFE method } \\
\hline Future FOE & $10.62 \%$ & $10.62 \%$ & $9.63 \%$ & $9.63 \%$ \\
\hline $\mathrm{FCFE}_{1}($ \$million) & 214.36 & 214.36 & 372.33 & 372.33 \\
\hline $\mathrm{NW}_{0}($ \$million $)$ & $4,765.74$ & $3,695.10$ & $9,665.19$ & $6,867.24$ \\
\hline $\mathrm{NW}_{0} / \mathrm{BE}_{0}$ & 2.36 & 1.83 & 2.50 & 1.78 \\
\hline
\end{tabular}

Table 4 reports the net worth valuation results for SU and IU, assuming social benefit fully converted to earnings. Panel A provides the inputs and assumptions for all methods used. Panel B provides the results for the EP to Equityholders method, and Panel C for the FCFE method. In Panel A of Table 4, the growth rate based on historical adjusted net earnings is $3.74 \%$ for $\mathrm{SU}$ and $4.38 \%$ for IU, and the growth rate based on historical revenues is $2.43 \%$ for $\mathrm{SU}$ and $2.81 \%$ for IU. They are much lower than the average growth rates of education companies (7.51\% and $7.68 \%)$. Thus, it seems proper to employ a one-stage constant growth pattern in the valuation of SU and IU. The capital structure of SU and IU is similar to that of the education companies, as supported by the data in Tables 2 and 3. Moreover, the discount rate used in the valuation process refers to the acquirers' cost of equity, and it is assumed to stay the same in the future. Therefore, the future cost of equity does not need to be adjusted for any change in capital structure. Finally, we assume that $100 \%$ of social benefit is converted to net earnings.

In Panel B of Table 4, the future ROE (based on adjusted net earnings) is $14.12 \%$ for SU and $14.22 \%$ for IU, roughly in line with the average ROE of education companies (12.95\%). For both universities, since the future ROE is larger than the cost of equity (8.24\%), the annual economic profit and the MVA to equityholders are positive, and the net worth exceeds the book equity. As shown, the net worth of SU is estimated to be $\$ 4.1$ to $\$ 4.7$ billion, which is 2.01 to 2.31 times the book equity. The net worth of IU is estimated to be $\$ 8.1$ to $\$ 9.9$ billion, which is 2.10 to 2.55 times the book equity.

In Panel C of Table 4, the future FOE (based on adjusted free cash flows) is $10.62 \%$ for SU and $9.63 \%$ for IU. As displayed, the net worth of SU is estimated to be $\$ 3.7$ to $\$ 4.8$ billion, which is 1.83 to 2.36 times the book equity. The net worth of IU is estimated to be $\$ 6.9$ to $\$ 9.7$ billion, which is 1.78 to 2.50 times the book equity.

\section{Breakeven: Partial Conversion of Social Benefit}

In the previous section, we report that the estimated net worth is higher than the book equity based on the best-scenario assumptions. In this section, we assume that less than $100 \%$ of social benefit is converted to profits. That is, one part of existing social benefit is converted to net earnings, and the other part is distributed to students as scholarship and financial aid. With lower adjusted net earnings and lower adjusted free cash flows, the net worth would become lower. If the net worth is reduced to the level of book equity (i.e., the breakeven situation), the required percentage of social benefit conversion can be estimated. 
Table 5. Breakeven: partial conversion of social benefit

Panel A. Inputs and assumptions

\begin{tabular}{|l|c|c|c|c|}
\hline \multirow{2}{*}{} & \multicolumn{2}{|c|}{ Syracuse University } & \multicolumn{2}{c|}{ Indiana University } \\
\cline { 2 - 5 } & Earnings growth & Revenues growth & Earnings growth & Revenues growth \\
\hline Future growth rate $(\mathrm{g})$ & $3.74 \%$ & $2.43 \%$ & $4.38 \%$ & $2.81 \%$ \\
\hline Future cost of equity $(\mathrm{k})$ & $8.24 \%$ & $8.24 \%$ & $8.24 \%$ & $8.24 \%$ \\
\hline $\mathrm{BE}_{0}(\$$ million$)$ & $2,017.59$ & $2,017.59$ & $3,865.54$ & $3,865.54$ \\
\hline $\mathrm{NW}_{0}(\$$ million$)$ & $2,017.59$ & $2,017.59$ & $3,865.54$ & $3,865.54$ \\
\hline $\mathrm{NW}_{0} / \mathrm{BE}_{0}$ & 1.00 & 1.00 & 1.00 & 1.00 \\
\hline
\end{tabular}

Panel B. EP to Equityholders method

\begin{tabular}{|l|c|c|c|c|}
\hline Future ROE & $8.24 \%$ & $8.24 \%$ & $8.24 \%$ & $8.24 \%$ \\
\hline $\mathrm{EP}_{1}($ million$)$ & 0.00 & 0.00 & 0.00 & 0.00 \\
\hline$\%$ of social benefit converted & $53.08 \%$ & $53.08 \%$ & $34.56 \%$ & $34.56 \%$ \\
\hline
\end{tabular}

Panel C. FCFE method

\begin{tabular}{|l|c|c|c|c|}
\hline Future FOE & $4.50 \%$ & $5.80 \%$ & $3.85 \%$ & $5.42 \%$ \\
\hline FCFE $_{1}(\$$ million$)$ & 90.75 & 117.04 & 148.91 & 209.58 \\
\hline$\%$ of social benefit converted & $51.17 \%$ & $61.56 \%$ & $36.78 \%$ & $53.95 \%$ \\
\hline
\end{tabular}

Table 5 reports the breakeven results for SU and IU, assuming net worth equal to book equity. In Pane A of Table 5, the growth rates, the cost of equity, and the book equity are the same as those in Panel A of Table 4. For the breakeven assumption, we set the net worth equal to the book equity. Thus, the net worth to book equity ratio is 1.00 accordingly.

In Panel B of Table 5, the future ROE is equal to the cost of equity, and the annual economic profit is zero, implying zero MVA to equityholders. Both the future ROE and $\mathrm{EP}_{1}$ are lower than those in Panel $\mathrm{B}$ of Table 4. In this situation, SU needs to convert $53.08 \%$ of existing social benefit to net earnings, and IU, $34.56 \%$.

In Panel C of Table 5, the future FOE is $4.50 \%$ to $5.80 \%$ for SU and $3.85 \%$ to $5.42 \%$ for IU. Both the future FOE and $\mathrm{FCFE}_{1}$ are lower than those in Panel $\mathrm{C}$ of Table 4. In this situation, SU needs to convert $51.17 \%$ to $61.56 \%$ of existing social benefit to net earnings, and IU, $36.78 \%$ to $53.95 \%$.

\section{Conclusions}

We use the DCF approach to estimate the net worth for two nonprofit universities: SU and IU, assuming they are the targets of acquisition by for-profits. We transform nonprofits to for-profits by converting nonprofit social benefit to net earnings and by adopting for-profit cost of equity and tax rate. These adjustments capture considerable hidden value to equityholders. The following provides a summary of our main results.

First, by using different valuation methods (EP to Equityholders and FCFE) and different growth rates (earnings and revenues), we show that based on the best-scenario assumptions, the net worth to book equity ratio is 1.83 to 2.36 for SU and 1.78 to 2.55 for IU in June 2017. These ratios of SU and IU are by and large consistent with the price/book ratio (1.95) of the for-profit education companies at the same time. Our best-scenario results can be regarded as the highest limits for the net worth in June 2017, and they are obtained under two conditions. That is, the existing social benefit could be fully converted to net earnings, and the potential loss of the public-and-government-supported fund revenues could be offset by the potential increase in tuition revenues. It is necessary to point out that the best-scenario results may be unrealistic in a real-world acquisition. They merely sketch the upper boundary in an ideal situation. The realistic values tend to lie below the upper boundary. Even so, the net worth is still likely to exceed the book equity, implying a positive MVA to equityholders.

Second, when the net worth breaks even at the book equity, as we find, SU needs to convert $51.17 \%$ to $61.62 \%$ of existing social benefit to net earnings, and IU, $34.56 \%$ to $53.95 \%$, while the rest is distributed to students as scholarship and financial aid.

Third, when acquired by for-profit companies, SU and IU in the worst situation would lose all the fund revenues (gifts or contributions, grants and contracts, and state appropriations). To make up for these losses and to maintain the same levels of total revenues, SU would have to increase tuition revenues by $20.89 \%$, and IU, $100.86 \%$. Therefore, SU relies much less on the public-and-government-supported fund revenues than IU. This is in line with the fact that the former charges much higher per-student tuition and fees than the latter.

Given the above findings, it is our responsibility to declare the constraints of our work. First, this study is not an all-around assessment of the nonprofit net worth. In an actual M\&A deal, strategic changes of nonprofits as they become for-profits need to be addressed, control premium and illiquidity discount need to be considered, and other valuation approaches need to be involved. Second, between the buyer and the seller and among diverse buyers, 
valuation results are inclined to vary due to various perspectives. Third, in a different time, the macroeconomic, industrial, and institutional conditions may differ from those in June 2017, leading to different valuation results.

Please note that the discussions in this paper do not represent opinions of any universities or any potential investors. They are only academic inquiries of the authors, and they serve as a discussion of nonprofit valuation in order to induce further inquiries.

\section{References}

Adelino, M., Lewellen, K., \& Sundaram, A. (2015). Investment decisions of nonprofit firms: Evidence from hospitals. Journal of Finance, 70, 1583-1628. https://doi.org/10.1111/jofi.12234

Bøhren, Ø., \& Josefsen, M. G. (2013). Stakeholder rights and economic performance: The profitability of nonprofits. Journal of Banking \& Finance, 37, 4073-4086. https://doi.org/10.1016/j.jbankfin.2013.07.021

Damodaran, A. (2012). Investment Valuation: Tools and Techniques for Determining the Value of Any Asset. John Wiley \& Sons, Inc.

Damodaran, A. (2018). The Dark Side of Valuation. Pearson Education, Inc.

Gertler, P., \& Kuan, J. (2009). Does it matter who your buyer Is? The role of nonprofit mission in the market for corporate control of hospitals. Journal of Law and Economics, 52, 295-306. https://doi.org/10.1086/596037

Jegers, M. (2011a). Financing constraints in nonprofit organisations: A 'Tirolean' approach. Journal of Corporate Finance, 17, 640-648. https://doi.org/10.1016/j.jcorpfin.2010.11.002

Jegers, M. (2011b). On the capital structure of non-profit organisations: A replication and extension with Belgian data. Financial Accountability \& Management, 27, 18-31. https://doi.org/10.1111/j.1468-0408.2010.00513.x

Jegers, M., \& Verschueren, I. (2006). On the capital structure of non-profit organisations: An empirical study for Californian organisations. Financial Accountability \& Management, 22, 309-329. https://doi.org/10.1111/j.1468-0408.2006.00428.x

Kalodimos, J. (2017). Internal governance and performance: Evidence from when external discipline is weak. Journal of Corporate Finance, 43, 193-216. https://doi.org/10.1016/j.jcorpfin.2017.01.005

Koller, T., Goedhart, M., \& Wessels, D. (2015). Valuation: Measuring and Managing the Value of Companies. John Wiley \& Sons, Inc.

Pinto, J., Henry, E., Robinson, T., \& Stowe, J. (2015). Equity Asset Valuation. John Wiley \& Sons, Inc.

\section{Notes}

Note 1. The website of SU is www.syracuse.edu. The website of IU is www.iu.edu. The website of Damodaran is pages.stern.nyu.edu/ adamodar/New_Home_Page/dataarchived.html.

Note 2. As Table 3 shows, the unadjusted net profit margin (i.e., net earnings/total revenues) is $1.88 \%$ for SU and $6.45 \%$ for IU, and the unadjusted return on equity (ROE) is $1.99 \%$ for SU and $6.42 \%$ for IU. These numbers are much lower than those of S\&P 500 index at the same time.

\section{Copyrights}

Copyright for this article is retained by the author(s), with first publication rights granted to the journal.

This is an open-access article distributed under the terms and conditions of the Creative Commons Attribution license which permits unrestricted use, distribution, and reproduction in any medium, provided the original work is properly cited. 